\title{
Individual and contextual explanations of attitudes towards immigration
}

Eva G. T. Green \& Oriane Sarrasin, University of Lausanne

Contact: eva.green@unil.ch

Green, E. G.T \& Sarrasin O. (2019). Individual and contextual explanations of attitudes toward immigration. In S. M. Croucher, J. R. Caetano, \& E. A.

Campbell (Eds). The Routledge Companion to Migration, Communication, and Politics (pp. 282-295). Routledge.

\begin{abstract}
Contemporary societies are more and more culturally diverse, largely due to immigration. At the same time anti-immigrant attitudes are arising and right-wing populist parties are gaining support. Uncovering the multiple reasons that explain the raise of intolerance is a major challenge. This chapter introduces multilevel research examining the interplay of individual and contextual accounts of anti-immigration attitudes and radical right-wing voting. This approach allows examining how individuals' attitudes are shaped by the socio-structural (e.g., immigrant ratio) and normative contexts (e.g., prevailing values) in which they develop, over and above the individual-level determinants of these attitudes (e.g., threat perceptions, personal experiences with immigrants, ideological orientations such as national attachment). The development of large-scale international social surveys has enabled comparative research between and within nations, that takes into account the impact of contextual factors on individual-level processes. Moreover, the necessary multilevel research designs can now be implemented with a number of statistical software packages. Our recent research conducted in Switzerland — a country with large immigrant presence — is presented to exemplify this research approach.
\end{abstract}




\section{Individual and contextual explanations of attitudes towards immigration}

Largely due to immigration, virtually all contemporary societies are becoming more and more culturally diverse. Immigration is frequently triggered by societal circumstances such as armed conflicts, global economic downturns or environmental crises, and can result in large flows of immigrants crossing international borders. The refugee crisis, that started in 2015, notably exemplifies a dramatic consequence of such events. Accordingly immigration has become one of the most polarizing topics in political and societal debates in receiving societies across the globe. Public opinion varies from exclusive to inclusive when it comes to receiving immigrants, providing them support, or granting them rights. Currently however anti-immigrant attitudes are on the rise, and in Europe in particular, right-wing populist parties are gaining support. Such a trend is clearly a risk for social cohesion and increases the stigmatization immigrants endure in the receiving societies. Uncovering the multiple reasons that explain the rise of intolerance towards immigrants is a major challenge.

The key question is thus which factors explain how members of receiving societies react to the increased and diversified immigrant presence. This chapter presents a multilevel research approach — in a non-statistical conceptual manner-for studying how the interplay of individual and contextual factors accounts for anti-immigration prejudice among members of the national majority (i.e., citizens with no foreign roots). Radical right voting can be seen as a behavioural manifestation of anti-immigration stances. Therefore, we also refer to multilevel research examining radical right voting intentions. ${ }^{1}$ Though immigration is a global phenomenon, as large scale international surveys on immigration attitudes have been mainly conducted in the global North, the existing multilevel research focuses on receiving countries in Europe. We first define a multilevel approach for studying immigration attitudes. Second, based on multilevel survey research drawing on social and political psychology, we present individual-level determinants of these viewpoints (i.e., threat perceptions, intergroup contact 
with immigrants, ideological orientations such as national attachment) that have been evidenced to play an important role in shaping immigration attitudes. Third, extending the theorization used to conceptualize individual-level explanations to a contextual level, we examine how individuals' attitudes are shaped by the contexts in which they are embedded.

In parallel, to illustrate this research approach, we present four examples of our recent research conducted on attitudes regarding immigration and radical right support in Switzerland. Switzerland is a highly relevant national context for studying immigration attitudes and radical right support with a multilevel perspective. Indeed, the proportion of immigrants within the Swiss population has historically been high (Piguet, 2009). In 2015 a quarter of the resident population (24.6\%) did not possess Swiss citizenship (Swiss Federal Statistical Office, 2017a). Both strict naturalization policies and continued immigration to Switzerland (in 2015 most immigrants— $80.6 \%$-were born abroad) explain this high immigrant proportion. Moreover, Switzerland is a decentralised federal state, in which political deliberation frequently occurs at the local regional level. Due to the political system practicing direct democracy, Swiss citizens have opportunities to express their views concerning immigration in local or national referendums. These referendums have frequently been initiated by the radical right Swiss People's party (in German, Schweizerische Volkspartei, SVP), the largest party in the Federal assembly ( $32.5 \%$ of the seats). In this context, radical right voting can be seen as a behavioural expression of anti-immigration prejudice. Note also that the Swiss national majority is composed of four language groups (approximately 63\% Swiss German speakers, 23\% French speakers, $8 \%$ Italian speakers, and less than 1\% Romansh speakers; Swiss Federal Statistical Office, 2017b), more or less located in linguistic regions. This both enriches and renders complex the study of immigration attitudes. $^{2}$

\section{A multilevel approach to study immigration attitudes}


A multilevel approach takes into account the impact of both individual and contextual factors on immigration attitudes (see Christ et al., in press; Pettigrew, 2006). The basic premise is that individuals are part of broader social contexts, which have the power to shape their attitudes (Hox, 2010). Thus it is likely that attitudes of individuals living within a given geographically delimited contextual unit are dependent. The characteristics of these units are assumed to explain a part of individuals' attitudes, over and above individual determinants. Contextual units can be distal, such as nations or regions, or more proximal such as districts, municipalities or neighborhoods. The choice of the level(s) of units to be examined in a specific study is driven by both conceptual (e.g., research questions) and methodological (e.g., data sampling) considerations. Figure 1 summarizes the basic multilevel model to which we refer to throughout the chapter. Note that, because we present results of multilevel regressions based on cross-sectional data, causality cannot be established. However, when discussing literature on antecedents of immigration attitudes in the next sections, we discuss theorydriven claims that imply direction.

While the importance of examining and articulating different levels of analysis in social psychology has been acknowledged and theorized previously (e.g., Doise, 1986; see Pettigrew, 2006), analytical techniques allowing to put multilevel models under empirical investigation have become available only the last 20 years. In statistical terminology, data requiring a multilevel approach is hierarchical, and individuals are nested within contextual (macro) units. Explanations can be conceptualised and variables can be defined at any level of this hierarchy. Preliminary tests ensure that a significant part of individuals' attitudes is due to them living within a given unit. If not, basic statistical tests (e.g., OLS regressions) can be performed and only the impact of individual characteristics is investigated. However, if such tests — based on the assumption of independence — are performed on data that are not independent, the reached findings are unreliable (i.e., the standard errors of conventional 
statistical tests are too small, see Hox, 2010). Instead, in these cases, multilevel research designs that combine individual-level (so-called level 1) predictors with macro-level (level 2) factors in a single explanatory model should be applied (see Figure 1). Such models can be implemented straightforwardly with a number of statistical software, such as STATA, SPSS, LISREL, MLwin, MPlus, R just to mention some of the most used in social sciences.

The advancement of software coincided with the development of high-quality largescale, international social surveys on immigration, which prompted a surge of cross-national and cross-regional research that simultaneously takes into account the impact of individual and contextual factors on attitudes. The European Social Survey (ESS http://www.europeansocialsurvey.org/) has monitored bi-annually the attitudes and practices of Europeans on a range of topics since 2002. An immigration module has been fielded twice, in 2002/2003 (Round 1, 22 countries), and in 2014/2015 (Round 7, 22 countries) partially repeating and developing the original module (see Heath, Schmidt, Green, Ramos, Davidov, \& Ford, 2012). The ESS survey has become the reference in cross-national research on immigration attitudes and explicitly encourages cross-national multilevel research by providing nation-level contextual variables. The International Social Survey Programme (ISSP http://www.issp.org), in turn, is the biggest and most extensive cross-national social survey endeavor with a yearly survey. The ISPP network was initiated in 1984 and currently includes around 50 countries worldwide. A National Identity module, that includes questions regarding attachment to the nation as well as attitudes towards immigrants, has been fielded three times $(1996,2003,2013)$. Other collective survey endeavors such as the World Values survey (http://www.worldvaluessurvey.org) and European Values Study (http://www.europeanvaluesstudy.eu/) also contain questions tapping into immigration attitudes, and have been widely used. 


\section{Individual-level explanations of immigration attitudes}

Many individual-level, socio-demographic and attitudinal, factors as well as contextual characteristics have been put forward to explain immigration attitudes and radical right voting. With a focus on three key social psychological explanations — threat perceptions, intergroup contact and national attachment (see also Green, Sarrasin, \& Fasel, 2015) — we now discuss individual-level antecedents of anti-immigration stances (Figure 1 bottom part). Building on this discussion, in the following section, contextual explanations using a multilevel approach are overviewed.

Threat perceptions. Perceptions that immigrants threaten the national majority is frequently argued to explain individuals' anti-immigrant attitudes. ${ }^{3}$ A number of theoretical approaches, such as Integrated Threat Theory (Stephan, Renfro, \& Davis, 2009) and Ethnic Competition Theory (Scheepers, Gjisberts, \& Coenders, 2002) have elaborated on the role of threat in determining immigration attitudes, albeit with somewhat different reasoning and focus. Threats are usually grouped into two major categories: realistic, material threats and symbolic, cultural threats (Riek, Mania, \& Gaertner, 2006). ${ }^{4}$ Material threat is associated with perceived competition for tangible, limited resources, such competition between immigrants and the national majority population in the labour and housing market as well as the perceived fiscal burden due to welfare benefits such as health care or integration measures for immigrants. Resources are thus conceived as a zero-sum, that is, an advantage for immigrants by default implies a disadvantage for the national majority (Esses, Jackson, \& Armstrong, 1998). The fear of immigrants accessing power and status, for example by claiming civic rights, is also in the realm of material threats. Cultural threat, in turn, derives from supposed differences between immigrants and natives in traditions, language and religion and thus the perception that immigrants undermine the values of the national majority. Fear of crime and terrorism - conveying material, physical threats as well as a symbolic threat of collapsing of 
Green \& Sarrasin

values-also underlie negative immigration attitudes. The populist right campaigns frequently present immigrants as both material and cultural threats thereby fostering harsh views concerning immigration.

Beneficial effects of intergroup contact. Whereas there is ample evidence that threat perceptions predict increased anti-immigration prejudice (Riek et al., 2006; Stephan et al., 2009) and radical right voting intentions (e.g., Lucassen \& Lubbers, 2012), other factors have the potential to curb anti-immigration stances. Indeed, there is evidence from over 60 years of research on intergroup contact that positive intergroup encounters with outgroup members reduce prejudice (Allport, 1954; Hewstone \& Swart, 2010; Pettigrew \& Tropp, 2006). Positive intergroup contact with immigrants has been shown to improve attitudes of the national majority (e.g., McLaren, 2003; Voci \& Hewstone, 2003) by reducing perceptions of threat and anxiety associated to immigrants and increasing empathy towards them (see Pettigrew \& Tropp, 2008 for a meta-analysis). Cross-group friendships-conveying deep and intimate encounters a national majority member can have with an immigrant outgroup member-are particularly powerful for reducing anti-immigrant attitudes (see Davies, Tropp, Aron, Pettigrew, \& Wright, 2011 for a meta-analysis). Indeed, analyses performed on the ESS immigration modules have demonstrated that having friends with foreign origins relates negatively to a range of anti-immigration viewpoints (Schneider, 2008; Semyonov \& Glickman, 2009), but the link to radical right support is equivocal (e.g., Rydgren, 2008). The ESS repeat module on immigration (Heath et al., 2012) contains a wider range of measures on different forms of intergroup contact that allow for example distinguishing close (i.e., intergroup friendships) as well as mundane contact experiences (i.e., in public transport, in the street, in shops or in the neighborhood).

National attachment as an ideology. Both threat perceptions and intergroup contact are related to how one perceives and interacts with immigrant outgroups. Yet, the way one 
relates with the national ingroup also plays a role for immigration attitudes. National attachment has been shown to relate to attitudes towards immigrants, however whether the relationship is positive or negative depends on the nature of national attachment. Two forms of national attachment—nationalism and patriotism — are generally distinguished (e.g., Blank \& Schmidt, 2003; Davidov, 2009; Wagner, Becker, Christ, Pettigrew, \& Schmidt, 2012). Nationalism refers to an uncritical attachment and idealization of the nation as well as a sense of national superiority with respect to other countries. This form of national attachment has consistently been associated with anti-immigration attitudes (Blank \& Schmidt, 2003). Patriotism, in turn, reflects pride in one's country, particularly in its democratic political institutions and does not involve comparisons with other countries (e.g., Mummendey, Klink, \& Brown, 2001). This form of attachment reflects a constructive and critical view of the nation. It is congruent with tolerance towards immigrants and frequently unrelated to immigration attitudes (e.g., de Figueiredo \& Elkins, 2003) or even linked to positive immigration attitudes (e.g., Blank \& Schmidt, 2003; see also Green, Sarrasin, Fasel, \& Staerklé, 2011). The ISSP national identity modules include questions tapping into these forms of national attachment, as well as others, and have thus prompted cross-national multilevel studies examining both the predictive power of nationalism and patriotism as well as their antecedents.

Whereas nationalism and patriotism convey ideological beliefs related to nationhood, it is important to acknowledge other ideological beliefs underlie immigration attitudes too. For example, rightwing authoritarianism, concerned with conformity and cohesion (Altermeyer, 1998), and social dominance orientation, a preference for group dominance and hierarchy (Sidanius \& Pratto, 1999) are also crucial antecedents of anti-immigration prejudice (Cohrs \& Stetzl, 2010; Sibley et al., 2013). Similarly, conservative values have been linked to anti-immigration attitudes (e.g., Fasel, Green, \& Sarrasin, 2013). 
Socio-demographic antecedents of anti-immigration attitudes. Socio-demographic variables are routinely added to multilevel models as predictors. Unlike in comparative sociology, their impact is more rarely theorised in social psychological research. Nevertheless, some elaboration is in order. The role of individuals' socioeconomic status on immigration attitudes is well studied (Ceobanu \& Escandell, 2010). The basic argument has been that citizens with a low status are more likely than their high-status compatriots to experience competition with immigrants on the job and housing markets, and therefore they should experience immigrants as more threatening and be more inclined to express an exclusionary anti-immigrant stance (Scheepers et al., 2002; see Lubbers, Gjisberts, \& Scheepers, 2002 regarding radical right support). While education, labor force status, occupation, and income are all intertwined manifestations of social status, their effects on immigration attitudes are not uniform (see Ceobanu \& Escandell, 2010): Higher level of education is quite systematically related to reduced expressions of anti-immigration stances (although attitudinal differences exist prior to entering education; Lancee \& Sarrasin, 2015), but the effects of other social status markers are inconsistent. Age and gender effects are also typically accounted for in multilevel studies on immigration attitudes. Older people often hold more conservative worldviews than younger people, which can explain harsher attitudes towards immigrants, and men express more negative attitudes than women (Ceobanu \& Escandell, 2010).

\section{Contextual explanations of anti-immigration attitudes}

The rationale of threat, intergroup contact and ideological beliefs (such as national attachment) driving immigration attitudes outlined above can be extended to a contextual level (see Figure 1 top part). We now discuss how contextual characteristics shape individuals' attitudes to immigration and radical right support. Multilevel survey research has heavily focused on the role of immigrant presence, typically tapped with the proportion of 
immigrants or increase in proportion, as characteristics of a given macro context, to understand negative attitudes towards immigrants (see Fasel et al., 2013 for an overview). The role of normative contexts on immigration attitudes, in turn, has only received attention more recently. We provide four examples from our research conducted in Switzerland that have contributed to this body of research.

Presence of immigrants: threat or opportunity? A threat reasoning has been applied in multilevel research to explain the impact of immigrant presence, with the rationale that a higher or an increasing ratio of immigrants triggers concerns over competition for scarce resources and fears of eradication of native traditions. Indeed multilevel research across European countries, has found evidence that immigrant ratios are related to increased threat perceptions and anti-immigrant stances (e.g., Green, 2009; Quillian, 1995; Scheepers et al., 2002) and radical right support (Lubbers et al., 2002). Perceptions of the number of immigrants explains part of this effect (mediates, in statistical terms): The greater the actual presence of immigrants in given place, the greater their perceived presence, which then drives more expressions of anti-immigrant stances (e.g., Semyonov, Raijman, \& Gorodzeisky, 2006).

Besides direct and indirect effects on immigration attitudes, contextual characteristics can also have interactive effects (level-2 interactions in multilevel terminology). That is, one contextual characteristic can curb or intensify the effect of another characteristic. Indeed, in support of the threat reasoning, a seminal study across 12 European countries by Quillian (1995) demonstrated that while the proportion of immigrants from non-European countries increased racial prejudice, this relationship was enhanced in countries with poor economic conditions. The same pattern was found for anti-immigrant prejudice, but the effect was less prominent.

Intergroup contact theory has argued however that immigration can have the opposite 
consequence to what just described: a strong presence of immigrants provides contact opportunities, and thereby facilitates positive intergroup encounters, which in turn reduce anti-immigrant attitudes. In a study across German districts, Wagner, Christ, Pettigrew, Stellmacher, and Wolf (2006) demonstrated that the proportion of immigrants was negatively related to immigrant prejudice. This relationship was explained by enhanced encounters with immigrants at the workplace and in neighbourhoods. Moreover, intergroup contact was related to improved attitudes towards immigrants by reducing perceived threat (see also Christ et al. 2014; Schmid, Al Ramiah, \& Hewstone, 2014). These seemingly contradictory threat and intergroup contact approaches can be reconciled as immigrant presence yields simultaneously different outcomes. Schlueter and Wagner (2008) for example found that the proportion of immigrant populations on the regional level within European countries was related to both intergroup contact and perceived threat.

Example 1. Disentangling threat and contact effects. In our research conducted in Switzerland (see Green, Fasel, \& Sarrasin, 2010 for details), we attempted to untangle the potential threat and contact effects of immigrant presence by differentiating between types of immigrant groups. To do so, we compared the impacts of the presence of devalued, stigmatized groups and of a valued, culturally close immigrants (e.g., Montreuil \& Bourhis, 2001) on threat perceptions and contact underlying anti-immigrant attitudes. Muslims - in Switzerland mainly originating from Turkey, former Yugoslavia and Albania - are more stigmatized than other immigrant groups in Switzerland (Helbling, 2010; Stolz, 2005) ${ }^{5}$ as well as elsewhere in Europe (e.g., Spruyt \& Elchardus, 2012). Indeed, a uniform group of Muslims does not exist as Muslim immigrants vary in economic, political and social status and as a function of the national context. Yet, while attitudes vary when it comes to specific Muslim groups or individuals for example due visible signs of religion (such wearing a head scarf) or associations to terrorism, the national majority representations of Muslims and Islam as a 
religion are quite homogeneous. Perceived as culturally similar, high skilled immigrants from the neighbouring northern and western European countries are more appreciated (e.g., Deschamps, Vala, Marinho, Costa Lopes, \& Cabecinhas, 2005; see however Binggeli, Krings, \& Sczesny, 2014; Matser, van Oudenhoven, Askevis-Leherpeux, Florack, \& Rossier, 2010). We used the first round of ESS data from Switzerland and examined the views of 1472 Swiss citizens across 185 municipalities to uncover how the presence of immigrants of different origins shapes citizens' attitudes. Municipalities are a relevant contextual unit for comparing the intergroup contact and threat rationale as when looking at immigrant presence on the municipality level it is plausible that encounters with immigrants occur in everyday life (see Wagner et al., 2006). This may not necessarily be the case when considering immigrant presence on the national level (see however, Pottie-Sherman \& Wilkes, 2017). The presence of immigrants in one part of the country does not necessarily translate into contact opportunities elsewhere. We found that the presence of valued, culturally close immigrants was related to heightened intergroup contact in municipalities. Indeed, it is likely that similarity and absence of a priori prejudice facilitate encounters. Contact was further associated to more inclusive immigration attitudes through reducing threat perceptions. The presence of devalued immigrants in municipalities, however, yielded a more intricate pattern: On the one hand, it was related to perceived threat which in turn was associated with increased anti-immigration prejudice (see also Savelkoul, Scheepers, Tolsma, \& Hagendoorn, 2011). On the other hand, presence of stigmatized immigrants was related to increased intergroup contact. These findings show that exposure to dissimilar types of immigrant groups differently shape immigration attitudes. More crucially, however, these findings imply that encouraging and enabling encounters with stigmatized immigrants is a route for more harmonious intergroup relations. Yet as the focus of the study was on attitudinal outcomes, we cannot conclude whether these processes play out when considering actual behaviour. We 
thus extended our research to political behaviour by examining voting intentions.

Example 2: From attitudes to political behaviour. Radical right campaigning in Switzerland, like elsewhere, uses threat images and rhetoric extensively when addressing immigration related issues, and in particular when referring to immigrants of Balkan and Muslim origin (see Ruedin, 2013 for an analysis of party manifestos; Sarrasin, Fasel, Green \& Helbing, 2015 for a study on the impact of radical right Swiss People's party SVP campaign posters). Thus, to further extend our examination of the impact of presence of stigmatized immigrants, we examined whether the proportion of stigmatized immigrants, from Former Yugoslavia and Albania, is associated with intentions to vote the radical right, SVP (for details see Green, Sarrasin, Baur, \& Fasel, 2016). We studied this question with data from the Swiss Election Studies (SELECTS) 2011 with 1736 Swiss citizens from 136 districts. We found that presence of Former Yugoslav and Albanian immigrants was related to increased voting intentions for the radical right through increased threat perceptions (see also Ford \& Goodwin, 2010). However, having positive intergroup encounters with Former Yugoslav and Albanian immigrants was related to reduced intentions to vote for the radical right. While actual presence of Former Yugoslav and Albanian immigrants was unrelated to contact, in districts with overall more positive encounters with Former Yugoslav and Albanian immigrants, threat perceptions and support for the radical right were lower. Our findings again speak to the importance of intergroup encounters in reducing anti-immigrant prejudice and in attenuating support for the radical right, and thus potentially curbing the rise of the populist right. While these findings on immigrant presence in Switzerland are promising, one cannot directly generalize from them to other countries. Indeed in a recent meta-analysis, Pottie-Sherman and Wilkes (2017) revealed that the type of immigrant presence is not a definite explanation for varying findings of immigrant presence found in the literature. While generalization is not possible, the findings of the two examples show that "valued" and 
"devalued" immigrants in the Swiss context relate to different reactions among the national ingroup. As whether a group is valued or devalued will vary across contexts, further research in different countries is needed to pursue this interpretation. Importantly, the normative climates needs to be considered too.

Normative climates and immigration. So far most multilevel research has focused on the impact of socio-structural features of national and regional contexts, such as immigrant ratio. Besides these features, contexts also have normative or ideological characteristics, referred to as normative climates. Individuals are embedded in these environments that provide guidance and information regarding the appropriate way to think about and deal with immigration (e.g., Green \& Staerklé, 2013; Guimond, Sablonnière, \& Nugier, 2014; Pettigrew, 2006). Indeed normative characteristics manifest themselves in different ways, and potentially have a great impact in shaping immigration attitudes. Normative contexts are formed for example by institutions, political parties as well as the attitudinal climate derived from the beliefs and values shared by fellow ingroup members. We now consider these different features and how they jointly influence individuals' attitudes regarding immigration. Institutional features of normative climates are conveyed through legislation and policies. They express governmental viewpoints and action toward cultural diversity and immigration, and thereby orient citizens' stances towards immigration. In a study across four countries, Guimond, Dambrun, Michinov, and Duarte (2013) showed that actual integration policies of countries affected perceived integration norms, which then predicted attitudes towards immigrants. These findings suggest that citizens have some awareness and are guided by the surrounding policy context when forming views regarding immigration. Indeed, in a study across 27 European countries, Schlueter, Meuleman, and Davidov (2013) considered more inclusive integration policies, to reflect tolerant institutionalized norms (measured by the Migrant Integration Policy Index MIPEX www.mipex.eu; Niessen, Huddleston, \& Citron 
2007), and found that they were related to reduced threat perceptions. The official views of political parties convey also visions on how cultural diversity and immigration should be dealt with. High presence of radical right parties in countries (Semyonov et al. 2006) has been used to tap exclusionary, normative climates. Indeed, such climates foster anti-immigrant attitudes beyond the individual characteristics driving such attitudes.

Whereas, policies and political parties express a normative climate that is defined topdown, shared ideological beliefs and values, in turn, circulating through citizens' everyday conversations and expressions regarding immigration within a given context convey bottomup normative climates. Shared ideological beliefs can be conceived broadly on a continuum from conservative and exclusive to progressive and inclusive. For example, shared exclusionary conceptions of who belongs to the national ingroup, measured with aggregated support for strict nationhood criteria (Pehrson, Vignoles, \& Brown, 2009) and an aggregated rightwing stance in countries and regions (van Assche, Roets, de Keersmaecker, \& van Hiel, 2016) have been used to depict bottom-up exclusionary normative climates. In the following two examples we consider the impact of both bottom-up and top-down forms of normative climates in Switzerland.

Example 3. Referenda results as normative climate. In our research comparing Swiss municipalities, we studied both the impact of immigrant presence and conservative vs. progressive normative climate on anti-immigrant views, more precisely opposition to antiracism laws (for details see Sarrasin, Green, Fasel, Christ, Staerklé, \& Clémence, 2012). With data from the first round of the ESS we studied the views of 1711 Swiss citizens from 176 municipalities. ${ }^{6} \mathrm{We}$ measured municipality-level conservative versus progressive normative climates via national referendum results on a range political topics (excluding referendums on immigration to avoid tautology in our analysis) over a period of ten years. Over and above individual-level antecedents, opposition to anti-racism laws was greater in conservative 
municipalities and intergroup friendships more frequent when proportion of immigrants was high. In addition, an interplay of municipality-level normative climate and proportion of immigrants (that is, a level-2 interaction in multilevel terminology) was revealed: In municipalities with a high immigrant proportion, conservative normative climates were unrelated to having friendships with immigrants, whereas in municipalities with a low proportion of immigrants, the more conservative the municipality, the less frequent were intergroup friendships. Put otherwise, in conservative municipalities with a low portion of immigrants, intergroup friendships were the rarest. Presence of immigrants thus seemed to buffer the impact of conservative contextual norms. Here we examined referenda results as a bottom-up manifestation of the normative climate in municipalities, while in the next example we investigate the role of both top-down and bottom-up normative climates.

Example 4. Comparing features of normative climates. Extending our work on contextual norms as antecedents of attitudes to examine political behaviour, we decided to study the relationship between normative climates and radical right voting intentions across Swiss cantons (for details see Baur, Green, \& Helbling, 2016). Moreover, whether top-down and bottom-up normative climates have similar effects on immigration-related attitudes begged for further inquiry. We thus set out to test whether canton-level institutionalised norms (top-down climates) and shared conservative values (bottom-up climates) similarly shape immigration attitudes and radical right voting intentions. We studied these questions with the 2011 Swiss Election Studies (SELECTS) with 3653 Swiss citizens in the 26 Swiss cantons. ${ }^{7}$ The institutional normative climate was tapped with an integration policy index developed by Manatschal (2011) and shared conservative values were based on aggregated attitudes from prior waves of the SELECTS Survey (i.e., items measuring preferences for a strong military, for law and order, preference for Swiss traditions, and for Swiss citizens having better chances than foreigners). As anticipated, in more exclusionary cantonal contexts 
(both institutionally more exclusive and with entrenched conservative beliefs) support for the radical right was greater than in more inclusive cantons, over and above the impact of individual political orientation or socio-demographic characteristics. Exclusionary cantonal norms were related to an anti-immigrant stance, which further fostered radical right voting intentions. Furthermore, we found that the relationship between immigration attitudes and radical right voting was reinforced in cantons with exclusionary normative climates (in multilevel modelling terminology, a cross-level interaction was revealed). This implies that individuals' attitudes towards immigration are a stronger driver of their voting intentions in exclusionary rather than in inclusionary contexts. This finding suggests that when individuals' attitudes match the surrounding normative climate they translate more readily into action, here voting for the radical right.

\section{Conclusion}

The aim of the current chapter was to showcase a multilevel approach that allows studying the impact individual- and context-level factors have in shaping attitudes towards immigration and radical right support. While the focus here was on predictors of negative immigration attitudes, one must recall that there are also individuals and popular movements reducing social inequalities, providing equal opportunities, and fighting discrimination. After describing the basic rationale of multilevel analyses, we overviewed both cross-national and cross-regional research on immigration attitudes and the principal explanations put forward in this approach. We focused on immigrant ratio and normative climates as context-level characteristics driving immigration attitudes. Our recent studies in Switzerland was showcased with four examples of this research approach. The decentralised political system that allows decision-making regarding immigration on the local level makes Switzerland a fascinating context for studying regional-level variation in immigration attitudes. As mentioned at the outset of the chapter, the cited multilevel research focusses on the standpoint 
of national majorities in receiving societies in the global North. We acknowledge that immigration between countries of global South is at least, if not more frequent, than SouthNorth immigration. However, currently most international surveys with large data collection endeavours (ESS and ISSP) that allow multilevel modelling have been carried out in the global North. The issues national majorities have with immigration as well as the contextual features driving stances towards immigration may differ drastically from the global South. For a comprehensive view of individual and contextual antecedents of immigration attitudes, it is imperative to broaden the sampling of countries.

There are a number of extensions of multilevel modelling that have been used to study immigration attitudes and related topics that are beyond the scope of this chapter. Indeed, multilevel structural equation modelling (Christ et al., in press) allows testing for more complex modelling. For example, multiple indirect effects (i.e., mediations) as well as multiple dependent variables (i.e. outcomes, such as different attitude constructs related to immigration) can be examined simultaneously. To this end, Schmid et al. (2014) examined effects of neighbourhood ethnic diversity on different forms of trust well as on outgroup attitudes, and showed that intergroup contact and perceived threat mediated these relationships. Moreover, it is important to take stock of the body of multilevel immigration research. Meta-analyses are well-suited tools because they allow exploring plausible explanations for contrasting findings and provide guidance of the generalizability of findings from individual studies. A multi-level meta-analysis, briefly evoked in the current chapter, has been recently conducted to statistically summarize research on the impact of immigrant presence on immigration attitudes (Pottie-Sherman \& Wilkes, 2017).

Whereas the chief asset of multilevel modelling is the possibility to jointly model macro- and individual-level explanations of individual attitudes, we acknowledge that no method alone permits unequivocal interpretations of the construction of attitudes towards 
immigration. Cross-sectional surveys need to be complemented with longitudinal surveys (allowing multilevel modelling) and experimental methods to determine causality. Moreover, self-report measures, such as survey questionnaires whether administered in a telephone or face-to-face interview, or self-administered with a paper-and-pencil or online questionnaire, need to be complemented. Interviews for example would allow gaining a deeper understanding of individuals' reasoning and reflectiveness underlying their stances regarding immigration. We examined radical right voting intentions to tap into actual political behaviour related to immigration. These intentions can have tangible consequences to organisation of society. Observational studies, however, would allow further insights regarding actual behaviour. Yet it is obvious that no research programme can combine all these methods. Using a multilevel approach in conjunction with another approach — be it a social psychological experiment to permit causal claims or a discursive analysis of everyday reactions to immigration — and triangulating the findings would be an ideal approach to aim for. 


\section{References}

Allport, G. W. (1954). The Nature of Prejudice. New York: Doubleday.

Altemeyer, B. (1998). The other "authoritarian personality". Advances in Experimental Social Psychology, 30, 47-92.

Binggeli, S., Krings, F., \& Sczesny, S. (2014). Perceived competition explains regional differences in the stereotype content of immigrant groups. Social Psychology, 45, 6270.

Blank, T., \& Schmidt, P. (2003). National identity in a united Germany: nationalism or patriotism? An empirical test with representative data. Political Psychology, 24, 289312.

Baur, R., Green, E. G.T., \& Helbling, M. (2016). Immigration-related political culture and support for radical right parties. Journal of Ethnic and Migration Studies, 42, 17481773.

Ceobanu, A. M., \& Escandell, X. (2010). Comparative analyses of public attitudes toward immigrants and immigration using multinational survey data: A review of theories and research. Annual Review of Sociology, 36, 15.11-15.20.

Christ, O., Hewstone, M., Schmid, K., Green, E.G.T., Sarrasin, O., Gollwitzer, M., \& Wagner, U. (in press). Advanced multilevel modeling for a science of groups: A short primer on multilevel structural equation modeling. Group Dynamics: Theory, Research, and Practice.

Christ, O., Schmid, K., Lolliot, S., Swart, H., Stolle, D., Tausch, N., Al Ramiah, A., Wagner U., Vertovec, S., \& Hewstone, M. (2014). Contextual effect of positive intergroup contact on outgroup prejudice. Proceedings of the National Academy of Sciences, 111, 3996-4000. 
Cohrs, J. C., \& Stelzl, M. (2010). How ideological attitudes predict host society members' attitudes toward immigrants: Exploring cross-national differences. Journal of Social Issues, 66(4), 673-694.

Davidov, E. (2009). Measurement equivalence of nationalism and constructive patriotism in the ISSP: 34 Countries in a comparative perspective. Political Analysis, 17(1), 64-82.

Davies, K., Tropp, L. R., Aron, A., Pettigrew, T. F., \& Wright, S. C. (2011). Cross-group friendships and intergroup attitudes: A meta-analytic review. Personality and Social Psychology Review, 15(4), 332-351.

De Figueiredo, R. J. P., \& Elkins, Z. (2003). Are patriots bigots? An inquiry into the vices of in-group pride. American Journal of Political Science, 47, 171-188.

Deschamps, J.-C., Vala, J., Marinho, C., Costa Lopes, R., \& Cabecinhas, R. (2005). Intergroup relations, racism and attribution of natural and cultural traits. Psicologia Politica, 30, 27-39.

Doise, W. (1986). Levels of explanation in social psychology. Cambridge: Cambridge University Press.

Esses, V. M., Jackson, L. M., \& Armstrong, T. L. (1998). Intergroup competition and attitudes toward immigrants and immigration: An instrumental model of group conflict. Journal of Social Issues, 54, 699-724.

Fasel, N., Green, E. G. T., \& Sarrasin, O. (2013). Facing cultural diversity. Anti-immigrant attitudes in Europe. European Psychologist, 18, 253-262.

Ford, R., \& Goodwin, M. J. (2010). Angry white men: Individual and contextual predictors of support for the British National Party. Political Studies, 58(1), 1-25.

Green, E. G. T. (2009). Who can enter? A multilevel analysis on public support for immigration criteria across 20 European countries. Group Processes \& Intergroup Relations, 12, 41-60. 
Green, E.G.T., Fasel, N., \& Sarrasin, O. (2010). The more the merrier? The effects of type of cultural diversity on exclusionary immigration attitudes in Switzerland. International Journal of Conflict and Violence, 4, 177-190.

Green, E. G. T., Sarrasin, O., \& Fasel, N. (2015). Immigration, Social Psychological Aspects. In J.D. Wright (Ed.) International Encyclopedia of the Social and Behavioral Sciences (2nd edition). Elsevier.

Green, E. G.T., Sarrasin, O., Baur, R., \& Fasel, N. (2016). From stigmatized immigrants to rightwing voting: A multilevel study on the role of threat and contact. Political Psychology, 37, 465-480.

Green, E.G.T., Sarrasin, O., Fasel, N., \& Staerklé, C. (2011). A Nationalism and patriotism as predictors of immigration attitudes in Switzerland: A municipality-level analysis. Swiss Political Science Review, 17, 369-393.

Green, E. G. T., \& Staerklé, C. (2013). Migration and multiculturalism. L. Huddy, D. O. Sears, \& J. Levy (Eds) Oxford Handbook of Political Psychology (pp. 852-889). Oxford University Press.

Guimond, S., Dambrun, M., Michinov, N., \& Duarte, S. (2003). Does social dominance generate prejudice? Integrating individual and contextual determinants of intergroup cognitions. Journal of Personality and Social Psychology, 84, 697-721.

Guimond, S., de la Sablonnière, R., \& Nugier, A. (2014). Living in a multicultural world: Intergroup ideologies and the societal context of intergroup relations. European Review of Social Psychology, 25, 142-188.

Heath, A., Schmidt, P. Green, E. G. T., Ramos, A., Davidov E., \& Ford, R. (2012). Attitudes towards immigration and their antecedents. European Social Survey Round 7 Question Module. 
Helbling, M. (2010). Islamophobia in Switzerland: A new phenomenon or a new name for xenophobia. In S. Hug \& H. Kriesi (Eds.), Value change in Switzerland (Vol. 65-80). Lanham: Lexington Press.

Hewstone, M., \& Swart, H. (2011). Fifty-odd years of inter-group contact: From hypothesis to integrated theory. British Journal of Social Psychology, 50, 374-386.

Hox, J. (2010). Multilevel Analysis: Techniques and Applications. New York : Routledge Academic.

Lancee, B., \& Sarrasin, O. (2015). Educated preferences or selection effects? A longitudinal analysis of the impact of educational attainment on attitudes towards immigrants. European Sociological Review, 31(4), 490-501.

Lubbers, M., Gijsberts, M., \& Scheepers, P. (2002). Extreme right-wing voting in Western Europe. European Journal of Political Research, 41, 345-378.

Lucassen, G., \& Lubbers, M. (2012). Who fears what? Explaining far-right-wing preference in Europe by distinguishing perceived cultural and economic ethnic threats. Comparative Political Studies, 45(5), 547-574.

Manatschal, A. (2011). Taking cantonal variations of integration policy seriously-Or how to validate international concepts at the subnational comparative level. Swiss Political Science Review, 17(3), 336-357.

Matser, C., Van Oudenhoven, J. P., Askevis-Leherpeux, F., Florack, A., Hannover, B., \& Rossier, J. (2010). Impact of relative size and language on the attitudes between nations and linguistic groups: The case of Switzerland. Applied Psychology, 59(1), $143-158$.

McLaren, L. M. (2003). Anti-immigrant prejudice in Europe: Contact, threat perception, and preferences for the exclusion of migrants. Social Forces, 81(3), 909-936. 
Montreuil, A., \& Bourhis, R. Y. (2001). Majority acculturation orientations toward "valued" and "devalued" immigrants. Journal of Cross-Cultural Psychology, 32(6), 698-719.

Mummendey, A., Klink, A., \& Brown, R. (2001). Nationalism and patriotism: National identification and out-group rejection. British Journal of Social Psychology, 40, 159171.

Niessen, J., Huddleston, T., \& Citron, L. (2007). Migration integration policy index. Brussels: British Council and Migration Policy Group.

Pehrson, S., Brown, R., \& Zagefka, H. (2009). When does national identification lead to the rejection of immigrants? Cross-sectional and longitudinal evidence for the role of essentialist in-group definitions. British Journal of Social Psychology, 48, 61-76. Pettigrew, T. F. (1959). Regional differences in anti-Negro prejudice. Journal of Abnormal Psychology, 59(1), 28-36.

Pettigrew, T. F. (2006). The advantages of multilevel approaches. Journal of Social Issues, 62(3), 615-620.

Pettigrew, T. F., \& Tropp, L. R. (2006). A meta-analytic test of intergroup contact theory. Journal of personality and social psychology, 90(5), 751-783.

Piguet, E. (2009). L'immigration en Suisse: soixante ans d'entrouverture (No. 24). Collection le savoir suisse.

Pottie-Sherman, Y., \& Wilkes, R. (2017). Does Size Really Matter? On the Relationship between Immigrant Group Size and Anti-Immigrant Prejudice. International Migration Review, 51, 218-250.

Quillian, L. (1995). Prejudice as a response to perceived group threat: Population composition and anti-immigrant and racial prejudice in Europe. American Sociological Review, 60, 586-611. 
Riek, B. M., Mania, E. W., \& Gaertner, S. L. (2006). Intergroup Threat and Outgroup Attitudes: A Meta-Analytic Review. Personality and Social Psychology Review, 10(4), $336-353$.

Ruedin, D. (2013). Obtaining party positions on immigration in Switzerland: Comparing different methods. Swiss Political Science Review, 19(1), 84-105.

Rydgren, J. (2008). Immigration sceptics, xenophobes or racists? Radical right-wing voting in six West European countries. European Journal of Political Research, 47(6), 737-765.

Sarrasin, O., Fasel, N., Green, E. G. T., \& Helbling, M. (2015) When sexual threat cues shape attitudes toward immigrants: the role of insecurity and benevolent sexism. Frontiers in Psychology. Personality and Social Psychology.

Sarrasin, O., Green, E. G. T., Fasel, N., Christ, O., Staerklé, C., \& Clémence, A. (2012). Opposition to anti-racism laws across Swiss municipalities: A multilevel analysis. Political Psychology, 33(5), 659-681.

Savelkoul, M., Scheepers, P., Tolsma, J., \& Hagendoorn, L. (2011). Anti-Muslim attitudes in the Netherlands: Tests of contradictory hypotheses derived from ethnic competition theory and intergroup contact theory. European Sociological Review, 27, 741-758

Scheepers, P., Gijsberts, M., \& Coenders, M. (2002). Ethnic exclusion in European countries. Public opposition to civil rights for legal migrants as a response to perceived ethnic threat. European Sociological Review, 18, 17-34.

Schlueter, E., Meuleman, B., \& Davidov, E. (2013). Immigrant integration policies and perceived group threat: A multilevel study of 27 Western and Eastern European countries. Social Science Research, 42, 670-682.

Schlueter, E., \& Wagner, U. (2008). Regional differences matter: Examining the dual influence of the regional size of the Immigrant population on derogation of immigrants in Europe International Journal of Comparative Sociology, 49(2-3), 153-173. 
Schmid, K., Al Ramiah, A., \& Hewstone, M. (2014). Neighborhood ethnic diversity and trust: the role of intergroup contact and perceived threat. Psychological Science, 25(3), 665674.

Schneider, S. L. (2008). Anti-immigrant attitudes in Europe: outgroup size and percieved ethnic threat. European Sociological Review, 24(1), 53-67.

Semyonov, M., \& Glikman, A. (2009). Ethnic residential segregation, social contacts, and anti-minority attitudes in European societies. European Sociological Review, 25(6), 693-708.

Semyonov, M., Raijman, R., \& Gorodzeisky, A. (2006). The rise of anti-foreigner sentiment in European societies, 1988-2000. American Sociological Review, 71(3), 426-449.

Sibley, C. G., Duckitt, J., Bergh, R., Osborne, D., Perry, R., Asbrock, F., Robertson, A., Armstrong, G., Wilson, M. S., \& Barlow, F. K. (2013). A dual process model of attitudes towards immigration: Person $\times$ residential area effects in a national sample. Political Psychology, 34(4), 553-572.

Sidanius, J., \& Pratto, F. (1999). Social dominance: An intergroup theory of social hierarchy and oppression. New York: Cambridge University Press.

Spruyt, B., \& Elchardus, M. (2012). Are anti-Muslim feelings more widespread than antiforeigner feelings? Evidence from two split-sample experiments. Ethnicities, 12(6), $800-820$.

Stephan, W. G., Renfro, C. L. \& Davis, M. D. (2008). The Role of Threat in Intergroup Relations. In U. Wagner, L. R. Tropp, G. Finchilescu \& C. Tredoux (Eds), Improving Intergroup Relations: Building on the Legacy of Thomas F. Pettigrew. Blackwell Publishing Ltd., Oxford.

Stolz, J. (2005). Explaining islamophobia. A test of four theories based on the case of a Swiss City. Schweizerische Zeitschrift für Soziologie, 31(3), 547-566. 
Swiss Federal Statistical Office (2014). Integration Indikatoren. Retrieved from http://www.bfs.admin.ch/bfs/portal/de/index/themen/01/07/blank/ind43.indicator.4301 4.430230.html

Swiss Federal Statistical Office (2017a). Population by place of birth. Retrieved from https://www.bfs.admin.ch/bfs/fr/home/statistiques/population/migrationintegration/selon-lieu-naissance.html

Swiss Federal Statistical Office (2017b). Population : Panorama. Retrieved from https://www.bfs.admin.ch/bfs/fr/home/statistiques/population.assetdetail.2241465.html

Van Assche, J., Roets, A., De keersmaecker, J., \& Van Hiel, A. (2016). The Mobilizing Effect of Right-Wing Ideological Climates: Cross-Level Interaction Effects on Different Types of Outgroup Attitudes. Political Psychology,

Voci, A., \& Hewstone, M. (2003). Intergroup contact and prejudice toward immigrants in Italy: The mediational role of anxiety and the moderational role of group salience. Group Processes \& Intergroup Relations, 6(1), 37-54.

Wagner, U., Becker, J. C., Christ, O., Pettigrew, T. F., \& Schmidt, P. (2010). A Longitudinal Test of the Relation between German Nationalism, Patriotism, and Outgroup Derogation. European Sociological Review, 28, 319-332.

Wagner, U., Christ, O., Pettigrew, T. F., Stellmacher, J., \& Wolf, C. (2006). Prejudice and minority proportion: Contact instead of threat effects. Social Psychology Quarterly, 69, 380-390. 


\section{Footnotes}

${ }^{1}$ We focus on antecedents of anti-immigration prejudice, as the consideration of other factors underlying radical right voting, such as political dissatisfaction, euroscepticism and distrust of elites, as well as party characteristics or electoral competition is beyond the scope of this chapter. In the current chapter, the term radical right is used to refer to political parties with an explicit anti-immigration agenda, and that have become mainstream political actors in Western countries. Right-wing extremist parties, that openly endorse for example neo-Nazi or racist viewpoints, are not considered here.

${ }^{2}$ The differences between linguistic regions in Switzerland are beyond the scope of this chapter. However, differences between linguistic regions are accounted for in the original papers of our research showcased here. In short, linguistic regions frequently differ in outcomes of referenda results concerning immigration as well as in attitudes as examined in social surveys. The German-speaking regions for example come across as having more negative views on immigration than the French-speaking regions. Yet, it is not possible to attribute these differences to language as the regions differ on other aspects too, with the Swiss-German region for example being markedly more rural than the Swiss-French region.

${ }^{3}$ Note that threat can be conceptualised as an antecedent of as well as a depiction of anti-immigration stances.

${ }^{4}$ Despite conceptually differentiating between dimensions of threat, empirically these dimensions frequently overlap, for example in factor analyses loading on the same factor. Thus general immigration threat is frequently studied (as predictor or as outcome).

${ }^{5}$ Immigrants from Former Yugoslavia and Albania report discrimination twice as often as West European or less recent immigrant groups (Swiss Federal Statistical Office, 
2014). While the nationalities from this region differ between each other in language and religion, the representations of these immigrant groups among the Swiss majority do not differ. Indeed, even the statistics on discrimination experiences immigrants from different countries of Former Yugoslavia and Albania are grouped together, suggesting similar reactions on the behalf of the national majority.

${ }^{6}$ Note that despite using the same data set, the $N$ of Example 1 and Example 3 differ because the variables used in the respective studies were not the same.

${ }^{7}$ Albeit using the same data set, the $N$ of Example 2 and Example 4 differ because the variables used in the respective studies were not the same. 
Figure 1. Multilevel model

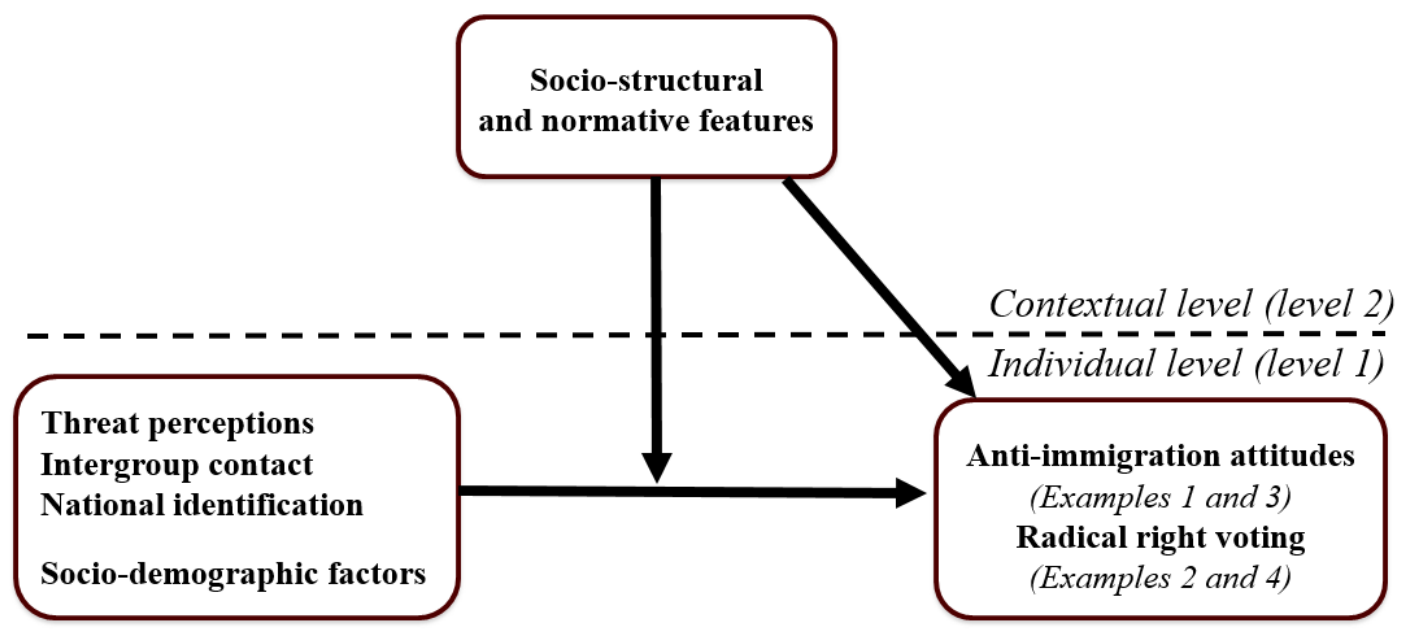

